\title{
The Alphabet Bomber A Lone Wolf Terrorist Ahead of His Time, by Jeffrey D. Simon, PhD., Lincoln, NE: University of Nebraska Press, Imprint: Potomac Books, 2019.
}

Millard E. Moon Ed.D., Colonel (ret.)

U.S. Air Force Office of Special Investigations

Follow this and additional works at: https://digitalcommons.usf.edu/jss

pp. 81-84

\section{Recommended Citation}

Moon, Millard E. Ed.D., Colonel (ret.). "The Alphabet Bomber A Lone Wolf Terrorist Ahead of His Time, by Jeffrey D. Simon, PhD., Lincoln, NE:

University of Nebraska Press, Imprint: Potomac Books, 2019.." Journal of Strategic Security 12, no. 2 (2019) : 81-84.

DOI: https://doi.org/10.5038/1944-0472.12.2.1746

Available at: https://digitalcommons.usf.edu/jss/vol12/iss2/6

This Book Review is brought to you for free and open access by the Open Access Journals at Digital Commons @ University of South Florida. It has been accepted for inclusion in Journal of Strategic Security by an authorized editor of Digital Commons @ University of South Florida. For more information, please contact digitalcommons@usf.edu. 
The Alphabet Bomber A Lone Wolf Terrorist Ahead of His Time, by Jeffrey D. Simon, PhD., Lincoln, NE: University of Nebraska Press, Imprint: Potomac Books, 2019. 


\section{The Alphabet Bomber A Lone Wolf Terrorist Ahead of His Time, by Jeffrey $D$. Simon, PhD., Lincoln, NE: University of Nebraska Press, Imprint: Potomac Books, 2019. ISBN-13: 978-1-61234- 996-1. 15 Photographs, 3 Illustrations, Index. Pp. 288. \$29.95}

A former analyst for the RAND Corporation, Jeffrey D. Simon, is the author of several books and articles on the terrorist threat. In addition to his writings in several journals, Simon is the author of The Terrorist Trap: America's Experience with Terrorism, and Lone Wolf Terrorism: Understanding the Growing Threat. Jeffery D. Simon is president of Political Risk Assessment Company, Inc., a security and terrorism research consulting company.

In this book Simon goes into a detailed study of the man who was called The Alphabet Bomber during his reign of terror in Los Angeles in 1974. Muharem Kurbegovic was an immigrant from Yugoslavia whose very rough and unhappy childhood may have had an impact on the disturbed personality who managed to wage war on Los Angeles, California. Kurbegovic was quite intelligent and was well regarded in the jobs he held as an engineer prior to his arrest. He did not want to be drafted during the Vietnam War, so he very successfully played the part of a mute individual in public and at work. This resulted in the draft board classifying him as unfit for service. He continued the charade in case some government agency should decide to check up on his claim of disability.

Simon draws a picture of a loner with little or no real human interaction. As an immigrant Kurbegovic frequented the Los Angeles taxi dance halls so popular at the time. The concept had taken root much earlier, and socially inept loners were especially drawn to these public establishments where for a fee, usually about nine dollars an hour, they were allowed to dance or sit and talk to one of the young women who earned half the fee while the owner of the taxi dance hall pocketed the other half.

Bright, though emotionally unbalanced in a very dangerous way, Kurbegovic decided to make his fortune as the owner of a taxi dance hall. This business venture required a license from the City of Los Angeles. Unfortunately, he had been arrested on a lewd conduct charge in one of the establishments by a vice officer. Acting as his own attorney, Muharem 
Kurbegovic actually won an acquittal in the case. The record of his arrest remained in LAPD files.

When he applied for a license to operate a taxi dance hall, Kurbegovic received initial approval, but the license application was rejected by the police commission review board. This apparently triggered a rage in Kurbegovic who then blamed the government and government officials all the way to the United States Supreme Court.

Kurbegovic launched his terror campaign to exact revenge by placing a bomb in a

locker at Los Angeles International Airport (LAX). In what is the first recorded bombing of an airport, the bomb went off on August 6, 1974 . Three people were killed and thirty-five others injured, some very seriously, and the airport was flooded with bomb threats.

A caller to the Los Angeles Herald Examiner identified himself as Rasim and claimed credit for the bombing as a member of the group Aliens of America. On August 9, 1974, Rasim called the CBS television station in Los Angeles and told them where to find an audio cassette about the airport bombing. The key to the locker where the airport bomb had been placed was also with the audiocassette.

Rasim was in fact Muharem Kurbegovic and he had acted alone. There was no Aliens of America group or any other organization involved in his terroristic actions. Further threats and communications followed and there were firebombs set at the homes of the three police commission board members who had denied his application to open a taxi dance hall. Other bombs were set and warnings issued with the individual bombs identified by a single letter of the alphabet. The resulting painstaking investigation eventually identified Kurbegovic as a suspect. The Los Angeles Police Department had a unit known as the Special Investigation Section, which had been identified in a highly critical press report as an unorthodox unit. They were highly skilled in surveillance, however, and did a great job in the takedown of Kurbegovic.

Jeffrey D. Simon does a really good job reporting the trial of Kurbegovic and the 
schemes he used to harass those he blames for his incarceration as he sits in

prison today. The entire picture painted by Simon shows just how brilliant and

dangerous a thoroughly unhinged lone wolf can be to society. Simon reinforces this concept with brief discussions of other lone wolf terrorists in United States history.

George Metesky placed thirty-three bombs in New York City between 1940 and 1956. Metesky took a break during World War II because he was a patriot, but his entire campaign was apparently triggered by a perceived injustice done him by Consolidated Edison in New York. Theodore Kaczynski, the Unabomber, sent devices from the late 1970's into the mid1990's before his brother alerted authorities as to his possible activities. Bruce Ivins, a U.S. Army microbiologist, was eventually identified as the man behind the anathrax attacks in 2001. All three seemed to suffer paranoia, delusions, or other mental illness. All of these disturbed individuals were able to carry out successful terror campaigns on their own, with no outside group or support.

In the chapter of his book dealing with lessons we can learn, Dr. Simon makes some interesting observations on lone wolf terrorists in general: they are a diverse collection of individuals, the media and the lone wolf can feed off each other, lone wolves like to talk through public outlets, they can be very creative, and lone wolves can use chemical or biological agents. These lessons and others simply point out the enormous difficulty faced by law enforcement and counterterrorism officials in dealing with these lone wolf operators.

Dr. Simon cautions against making mentally ill individuals "scapegoats" for lone wolf attacks. Although many lone wolf attackers have mental or emotional problems, most have not been seen to suffer to a degree where they are not criminally responsible for their actions. As professionals, we need to prepare for an expansion of lone wolf operators attacking in a variety of ways.

There are major difficulties in preparing to defend these types of attacks. As Simon points out, we cannot stigmatize all individuals suffering from some form of mental or emotional problems as potential lone wolf terrorists. At the same time, with no formal organizations or identifiable 
associates, efforts to control these type attacks are reactive, not proactive. As professionals in law enforcement, security, intelligence, and counterintelligence, we all need to make a real effort to try to identify an early detection method for possible lone wolf operators. No citizen of the United States wants to suspend civil liberties or live in a police state. However, to meet the changing threat, professionals may need to propose some methods to balance our individual rights and still provide safety and security for the innocent citizens we protect.

Millard E. Moon, Ed.D., Colonel (ret.), U.S. Air Force Office of Special Investigations 